DOI: $10.19195 / 0137-1150.167 .47$

\author{
ELŻBIETA TYSZKOWSKA-KASPRZAK
}

Uniwersytet Wrocławski, Polska

\title{
„Смерти ведь - и дурак знает - нет, но есть разложение тканей”. Телесный аспект смерти в прозе Михаила Шишкина
}

В творчестве Михаила Шишкина смерть является доминирующей темой. Она реализуется как рассуждение о бренности человеческой жизни, умирании другого и своем, о бессмертии и посмертном существовании. Сам писатель подчеркивает, что данные проблемы присутствуют во всех его произведениях: „Конечно же, я пишу не романы, а один текст, в котором я пытаюсь ответить на одни и те же вопросы". Тему смерти в разное время в различных произведениях он раскрывает по-разному, в зависимости от изменяющихся взглядов на эту проблему:

В „Измаиле” для себя я отвечаю, что смерть - это враг. Или вернее так, что жизнь - это враг. Жизнь нужно брать как крепость. Со смертью нужно бороться, бороться нужно детьми и искусством, прозой, словами, собиранием коллекции. [...] Потом в „Венерином волосе” [...] главный враг - это время. Нужно бороться со временем, преодолевать время. Царь Ирод - это время, которое пожирает своих детей. Нужно быть Ксенофоном, который приводит греков к океану бессмертия. [...] Сейчас в новом романе „Письмовник” на все эти вопросы ответы пришли уже совсем другие: смерть - это не враг. Это дар, это великое счастье. Особенно смерть близких людей, которых ты любишь. Дар, который помогает тебе понять, кто ты, зачем ты здесь, что задумано тобой, твоим появлением на свет ${ }^{2}$.

Многие литературоведы, исследуя произведения Шишкина, сосредоточивали внимание на духовной стороне смерти, ее философском и религиоз-

${ }^{1}$ С. Иванов, М. Шишкин, Писатель должен ощутить всесилие?, „Контракты.UА” 4.08.2010, http://apps.kontrakty.ua/coffe/17-mikhail-shishkin/32-pisatel-dolzhen-oshhutit-vsesilie. $\mathrm{html}$ [дата обращения: 22.06.2017].

2 Там же. 
ном толковании, и прежде всего на воскресении и бессмертии ${ }^{3}$. Но не менее существенным представляется ее физический, телесный аспект, который до сих пор не нашел своего отражения в критических и научных работах.

В творчестве Шишкина можно обнаружить целый спектр танатологических мотивов, выделяемых с учетом причины смерти ${ }^{4}$. Во всех произведениях писателя, из которых самые известные - романы: Взятие Измаила (2000), Венерин волос (2005), Письмовник (2010), присутствует описание смерти как насильственной, так и естественной. Смерть насильственная представлена в образах криминальных и ритуальных убийств, казни, смерти во время военных действий, самоубийств. В свою очередь естественная смерть вызвана болезнями, старостью и бренностью жизни.

В изображении смерти и процесса умирания в прозе Шишкина заметно разделение на сферы духовную и телесную. Дуализм человеческой сущности душа-тело 5 выражается непосредственно в словах героев его романов: „Отнимите у тела душу, и вы получите труп”б; „Прочитал, не помню где,

${ }^{3}$ См., напр.: Д. Бавильский, Шишкин лес, „Частный Корреспондент” 11 августа 2010, http://www.chaskor.ru/article/shishkin_les_19083 [дата обращения 12.02.2016]; C. Оробий, Словом воскреснем: истоки и смысл прозы Михаила Шишкина, „Знамя” 2011, № 8, с. 184-191; С. Н. Лашова, Мотив воскрешения в прозе М. Шишкина, „Гуманитарный вектор” 2011, № 4, cyberleninka.ru/article/n/motiv-voskresheniya-v-proze-m-shishkina [дата обращения 23.03.2017]; С. Н. Лашова, Поэтика Михаила Шиикина: система мотивов и повествовательные стратегии, Автореферат на соискание ученой степени кандидата филологических наук, Пермь 2012; А. Скотницка, Мотив ребенка и семьи в прозе Михаила Шишкина. Постановка вопроса, „Уральский филологический вестник” 2014, № 4, с. 77-89; М. А. Хлебус, Слово как предмет художественного осмысления в романе М. П. Шишкина „Письмовник”, „Современная наука: актуальные проблемы теории и практики”. Серия: „Гуманитарные науки" 2017, № 2, с. 88-90; И. Мотеюнайте, Слово как способ преодоления времени в романах Михаила Шишкина и Евгения Водолазкина, [в:] Знаковые имена современной русской литературыл. Михаил Шишкин, ред. А. Skotnicka и J. Świeży, Kraków 2017, с. 227-238; Г. Нефагина, „Все дело в рифмах”: симметрия в романе Михаила Шиикина „Письмовник”, [в:] Знаковые имена современной русской литературы. Михаил Шишкин, ред. A. Skotnicka, J. Świeży, Kraków 2017, c. 203-214.

4 См.: А. Бабаянц, Несколько замечаний о категории смерти в литературе, „Начало”, вып. 5, Москва 2002, с. 52-64; Р. Красильников, Танатологические мотивы в художественной литературе, Москва 2015, с. 97-102.

5 О библейских, мифологических и народных источниках представления оппозиции тело-душа см.: Т. Цивьян, О телесности души в русской литературе (Постановка вопроса и некоторые примеры), „Wiener Slawistischer Almanach” Тело и душа в русской литературе и культуре, т. 54, 2004, с. 7-18; ее же, Отношение к себе и к своему телу в русской модели мира, [в:] Тело в русской культуре. Сборник статей, сост. Г. И. Кабакова, Ф. Конт, Москва 2005, с. 38-48; С. Толстая, Тело как обитель души: славянские народные представления, [в:] Тело в русской культуре. Сборник статей, сост. Г. И. Кабакова и Ф. Конт, Москва 2005, c. 51-66.

${ }^{6}$ М. Шишкин, Взятие Измаила, Москва 2001, с. 13. В дальнейшем цитаты из этого произведения буду приводить по тому же изданию с указанием в скобках инициала заглавия ВИ и номера страницы. 
что душа, как и тело, пахнет собой и своей пищей”, ; „[...] выяснилось, что после агонии и смерти масса тела уменьшается в среднем на пять граммов. [...] Это вес человека в чистом виде, без тела. Назови это как хочешь - душой, квинтэссенцией, пыльцой” [BВ, с. 420], „Где-то прочитала, что самые пахучие части тела ближе всего к душе"8, или, наконец, предложение, взятое в заглавие настоящей статьи: „Смерти ведь - и дурак знает - нет, но есть разложение тканей” [ВИ, с. 181].

Девальвация тела заметна в русской культуре уже на рубеже XVIIIXIX веков. Константин Богданов усматривает в этом влияние рассуждений Декарта, для которого тело по отношению к душе - вторично 9 . Интерес к человеческому телу - его анатомии и физиологии - в России появился значительно позже, чем в Западной Европе, в связи с чем особенно ценились врачи-иностранцы. В то же время в русской литературе врач как человек, занимающийся исключительно телом, оказывается чужд и всему русскому (поскольку он, как правило, иностранец) и всему, что имеет отношение к душе ${ }^{10}$. Этим объясняются разные подходы к смерти тела и существованию души.

Некое пренебрежение к телу (по сравнению с духовностью) было свойственно христианской культуре, и лишь в ХХ веке французский феноменолог Морис Мерло-Понти дал оценку первичной сути телесности, рассматривая тело как способ постижения мира ${ }^{11}$. По мнению философа, сенсуальная перцепция окружающей действительности непосредственно связана с телом именно оно становится местом встречи субъекта и мира, таким образом играя ключевую роль в познании мира и самого себя ${ }^{12}$.

Описание умирания и смерти в произведениях Шишкина нередко сопровождается рассуждениями о ее сути, и здесь можно отметить свое-

${ }^{7}$ М. Шишкин, Венерин волос, Москва 2012, с. 470. В дальнейшем цитаты из этого произведения буду приводить по тому же изданию с указанием в скобках инициала заглавия ВВ и номера страницы.

Та же мысль появляется в романе и второй раз: „Вам я кажусь знакомым, потому что мы все по образу и подобию: ручки, ножки, огуречик, а душа, как и тело, пахнет собой и своей пищей” [BВ, с. 636].

${ }^{8}$ М. Шишкин, Письмовник, Москва 2016, с. 21. В дальнейшем цитаты из этого произведения буду приводить по тому же изданию с указанием в скобках инициала заглавия П и номера страницы.

${ }^{9}$ К. А. Богданов, „Тела, тела, тела...”: к истории медицинского дискурса в русской литературе, „Wiener Slawistischer Almanach”, т. 49, 2002, с. 145.

10 Там же, с. 144.

11 J. Migasiński, Percepcja i ciało, [в:] его же, Merleau-Ponty, Warszawa 1995, c. 33.

12 M. Kowalska, Relacja cielesność - rzeczywistość jako rodzaj doświadczenia $w$ filozofii Maurice'a Merleau-Ponty'ego i jego odniesienie do widzenia obrazu malarskiego, „Humaniora. Czasopismo Internetowe” 2014, № 1, с. 50. См. также: K. Gurczyńska-Sady, Problem ciała i przyszłość ludzkości, czyli na co komu dwudziestowieczna filozofia, „Analiza i Egzystencja” 2011, № 15, c. 133. 
образную полифонию (по определению Михаила Бахтина ${ }^{13}$ ): герои высказывают нередко противоречивые мнения и репрезентируют разные верования и представления как о самом переходе, так и возможности и способе существования после кончины ${ }^{14}$. Как правило, осмысление смерти можно отнести к уровню возвышенных, бытийных элементов, но автор Взятия Измаила не избегает и бытового, реалистического, а местами и натуралистического описания самого процесса умирания и мертвого тела, что относится уже к сфере низменного ${ }^{15}$.

Герои прозы Шишкина неоднократно высказывают мнение, что тело обременяет человека, является причиной его несовершенства, ограничивает жизнь во времени: „Тело так быстро проходит” [BВ, с. 509] - с тревогой констатирует героиня Венериного волоса. Больше всего рассуждений на тему бренности жизни представлено в романе Письмовник. Главный герой Владимир вспоминает ужас, с которым он осознал природу человеческого тела: „Знаешь, отчего стало страшно в первый раз - мне было четырнадцать или пятнадцать - оттого, что вдруг пришло озарение: мое тело тянет меня в могилу. Каждый день, каждое мгновение. С каждым вдохом и каждым выдохом" [П, с. 210]. Писатель толкует умирание тела не как момент кончины, а как непрерывный процесс:

Читал о реинкарнации, потом решил побриться. Смотрю на свою седую щетину и понимаю, что переселение душ происходит постоянно, просто мы переселяемся сами в себя. Был мальчик, стал старик, и душа переселялась из тела в тело бесчисленное количество раз - каждое утро. Тело незаметно за ночь становится другим [П, с. 382].

Эта мысль сходна с рассуждениями о смерти многих философов, в том числе и Мартина Хайдеггера, который определяет человеческую жизнь как „бытие к смерти”. Философ и обращает внимание на тенденцию отвержения мысли о смерти, отталкивания ее в неопределенное будущее, что не совпадает с сутью экзистенции как „бытия во времени”. Для Хайдеггера

13 М. Бахтин, Проблемы поэтики Достоевского, Москва 1963.

14 Диалогизм романов Достоевского Леонид Гроссман объясняет противоречиями в мировоззрении писателя. Л. Гроссман, Путь Достоевского, [в:] его же, Собрание сочинений в 5 moмax, т. II, Москва 1928, с. 14. В свою очередь Михаил Бахтин определяет этот прием как „полифонический принцип построения целого”. М. Бахтин, Проблемыл.., с. 58. Для определения творческого метода Шишкина можно применить, скорее всего, толкование Бахтина. Произведения, создаваемые писателем как одна КНИГА, составлены из множества историй различных героев. Они, на первый взгляд, ничем не связаны между собой, но на самом деле эта коллекция событий, воспоминаний, впечатлений создает образ мира, космоса, а разные, часто противоречащие друг другу, взгляды на смерть представляют разнообразие понимания смерти в культурах, религиях, философских системах и индивидуальных представлениях людей, дают дифференцированный образ танатологической мысли. См. также: А. А. Сыродеева, Полифония как принцип целостности, „Вопросы философии" 2008, № 3, с. 172-175.

15 См. об этом: Р. Красильников, Танатологические мотивы..., с. 324-344. 
смерть это не только момент, заканчивающий жизнь, но определение этой жизни в ее течении ${ }^{16}$.

Шишкин нередко изображает изменения, которым подвергаются тела персонажей, умирающих по причине старения или болезни. Некоторые персонажи явно не отождествляются с собственным телом:

Мне казалось, что на мне, на моей телесной поверхности нарастает что-то не мое, чужое. Я сама по себе, а эта женщина, которой обрастаю, - сама по себе [BВ, с. 415];

Тело свое я не любил и презирал, кажется, с той самой отроческой поры, когда вдруг осознал, что я - это не совсем оно, а оно - это совсем не я. Странно было, что на призывной комиссии во время медицинского осмотра снова, как когда-то маму в детстве, кого-то интересовал мой вес, рост, зубы, и аккуратно заносились на бумагу все эти цифры, не имеющие собственно ко мне никакого отношения [П, с. 210].

В произведениях Шишкина многократно появляется образ героя, рассматривающего себя в зеркале и чувствующего отчужденность от своего тела: „Рассматривает себя с зеркальцем [...] Думает: где я и где не я? Кожаэто граница? Или двойник? Или мешок, в который меня засунули и куда-то тащат? И что от меня останется за вычетом тела?” [BВ, с. 146]. Изабеллу из Венериного волоса часто удивляет ее зеркальное отражение, воспринимаемое ею в разные моменты жизни как чужое. Саша, героиня Письмовника, стоя перед зеркалом, также задумывается о своей наружности:

Девочкой я часами вглядывалась в зеркало. [...]

А вдруг это не я? И это не мои глаза, не мое лицо, не мое тело.

А вдруг я - с этими глазами, лицом и промелькнувшим телом - это только воспоминание какой-то старухи, которой я когда-нибудь стану?” [П, с. 28].

Временность телесного существования выражена здесь и в сопоставлении контрастных периодов жизни (девочка-старуха), и в определении „промелькнувшее тело". Отец Саши на склоне лет записывает в своем дневнике наблюдения над измененным временем телом, что приводит его к мысли о смерти:

Прислушиваешься ночью к часам — как они забирают жизнь. [...] И вот среди бессонницы стоишь в ванной голый, стареющий - перед зеркалом. Смотришь на тело - предающее. Под бесцветными глазами набрякшие мешки, из ушей торчат космы. И чешешь себе между лопатками зубной щеткой. И думаешь - скоро умирать. Как так получилось? [П, с. 381].

И другому персонажу этого романа трудно смириться со своим старением и угасанием тела: „Смотрела в зеркало на складки вокруг глаз, сухую кожу на щеках, увядающую шею. [...] Думала: как же так - вот вены разбежались ручейками по ногам, волосы на лобке седеют. А это уже давно началось расставание с телом" [П, с. 239].

${ }^{16}$ M. Heidegger, Śmierć jako fakt biologiczny i jako fenomen egzystencji, пер. M. Skwieciński, [в:] Filozofia egzystencjalna, сост. L. Kołakowski i K. Pomian, Warszawa 1965, c. 271-272. См. также: K. Michalski, Heidegger i filozofia wspótczesna, Warszawa 1978, c. 127. 
С одной стороны, герои Шишкина понимают, что существуют благодаря своему телу, что ориентируются в мире благодаря осознанию его свойств и границ ${ }^{17}$, с другой - резко ощущают отчужденность собственного сознания от тела. Это двойственное отношение человека с самим собой отмечалось Жан-Полем Сартром в рассуждениях о теле и отношениях с другим ${ }^{18}$. Изменения тела герои наблюдают и у других, чаще всего - у своих близких, как, например, Саша, описывающая с неким удивлением наружность старого отца: „Кожа дряблая, болтается, будто соскальзывает с тела. Промываю ему все складки, морщины” [П, с. 384]. Эффект контраста создает сопоставление с воспоминанием героини об отце в молодости: „Я помню отца молодым, сильным [...] он вытягивал руку, а я цеплялась за его запястье и раскачивалась” [П, с. 383]; „, куда же делась та крепкая мускулистая рука" [П, с. 384]. Похожие замечания Саша делает, ухаживая за умирающей матерью:

Я мыла ее в ванной и удивлялась - неужели это мама? Волосы она давно не красила. Сверху каштановые, а у корней - все седое. Огромные безобразные шрамы вместо груди. Внизу, между ног, серые безжизненные клоки. На ногах выпирали варикозные вены - вереницы синих и багровых шишек [П, с. 329-330].

В автобиографической части Взятия Измаила Шишкин поместил сходные суждения об увядающем теле смертельно больной матери. Автор намекает на это и в рассказе Пальто с хлястиком $(2010)^{19}$.

${ }^{17}$ Cp.: A. Giddens, Ciało i świadomość, [в:] его же, Nowoczesność i tożsamość. „Ja” $i$ spoteczeństwo w epoce późnej nowoczesności, пер. A. Szulżycka, Warszawa 2002, c. 79; M. D. Goutierre, Ludzkie ciało: uwarunkowanie i osoba, [в:] еe же, Człowiek w obliczu własnej śmierci. Absurd czy zbawienie?, пер. A. Kuryś, Kraków 2001, c. 72-73.

18 Ж.-П. Сартр, Бытие и Ничто, пер. В. И. Колядко, Москва 2000, http://psylib.org.ua/ books/sartr03/txt07.htm [дата обращения: 12.03.2017]. Свои рассуждения о теле Сартр начинает мыслью: „Проблема тела и его отношений с сознанием часто была затемнена тем фактом, что тело прежде всего рассматривают как определенную вещь, имеющую свои собственные законы и поддающуюся определению извне, тогда как сознание постигают глубокой интуицией, которая свойственна ему. В самом деле, если, постигнув «мое» сознание в его абсолютной глубине и посредством ряда рефлексивных актов, я попытаюсь соединить с ним определенный живой объект, образованный нервной системой, мозгом, железами, органами выделения, дыхания и кровообращения, сама материя которых может быть проанализирована химически в атомах водорода, азота, фосфора и так далее, то я встречусь с непреодолимыми трудностями; но эти трудности проистекают из того, что я пытаюсь соединить мое сознание не с моим телом, но с телом других".

${ }^{19}$ В рассказе Пальто с хлястиком и романах Взятие Измаила и Письмовник представлен сюжет о матери, умирающей от рака груди. Эта история, как писатель признается в рассказе, основана на его личном опыте: „Потом я описал это во «Взятии Измаила»: ее соседку в больнице, лысую от химиотерапии и не снимавшую беретку, отчего она была похожа на художника с карикатур; как разлетались по палате обрезки ее ногтей, отросшие на скрюченных пальцах ног, когда я неуклюже пытался их постричь; как я принес ей доски на кровать, потому что мама не могла заснуть на больничной продавленной сетке. Роман, написанный через несколько лет после маминой смерти, начинался в русской литерату- 
Разрушение тела представлено в Письмовнике на примере не только пожилых, но также и больных людей. Соня - маленькая девочка — вследствие несчастного случая находится в коме, и ее тело, совсем еще юное, увядает, слабеет. В очень трогательном обращении к ней Саша уверяет, что тело уже непригодно для нее, и уговаривает девочку покинуть его:

Поверь мне, если бы ты посмотрела на свое тело, то ты поняла бы сразу, что оно больше не может служить тебе. Тебе не нужно больше за него держаться. [...] Ты только посмотри на это тело, оно стало тебе совсем ненужным. Оно не может больше танцевать, никогда не сможет делать реверансы. Ни бегать, ни скакать, ни рисовать, ни на улицу выйти. Когда оно умрет - это будет здорово. Пойми, жизнь — это расточительный дар. И все в ней — расточительно. И твоя смерть - это дар. Дар для любящих тебя людей. Ты умираешь ради них. [...] А тело - это просто тело. Ты же вырастаешь из своих балетных тапочек? Просто ты из него выросла [П, с. 277-278].

В телесном аспекте смерти — в образах умирания, мертвого тела в прозе автора Письмовника выражено современное отношение к этим явлениям в европейской культуре. Итак, сегодня отношение к кончине и покойникам имеет полярно-полюсный характер. С одной стороны, существует табу смерти - она уже не присутствует постоянно в мыслях людей, исчезают народные обычаи и коллективная солидарность, умирающие исключаются из общества — наступает медикализация смерти, последний этап жизни, агония проходят в больнице, похороны устраивают созданные для этого фирмы ${ }^{20}$. Такой подход Филипп Арьес определяет как „смерть перевернутая":

Смерть начали запирать в научных лабораториях, в клиниках, где уже не было места эмоциям. В этих условиях лучше было молчаливо условиться о соучастии во взаимной лжи. [...] Сейчас массовое общество восстало против смерти. Точнее, оно стыдится смерти, больше стыдится, чем страшится. Оно ведет себя так, как будто смерти не существует. Если чувство „другого”, доведенное до самых крайних логических следствий, является первой причиной того поведения перед лицом смерти, какое мы наблюдаем в наши дни, то вторая причина - стыд и запрет, налагаемый этим стыдом ${ }^{21}$.

Похожий взгляд можно найти в высказывании английского социолога Джефрея Горера, утверждающего, что для западного общества смерть ста-

ре, в нем было много цитат, связей, переплетений, а к концу я просто описывал то, что было в моей жизни. От сложного к простому. От книжного, начитанного - к маминому лифчику, набитому поролоном, который она надевала после того, как ей отрезали грудь. От старославянских центонов - к ее тихой смерти, которую она так ждала, чтобы отпустили боли”. М. Шишкин, Пальто с хлястиком, [в:] его же, Пальто с хлястиком. Короткая проза, эссе, Москва 2017, с. 21.

${ }^{20}$ M. Vovelle, Pod znakiem ,śmierci tabu”, [в:] его же, Śmierć w cywilizacji Zachodu. Od roku 1300 po wspótczesność, пер. T. Swoboda, M. Sawiczewska-Lorkowska, D. Sebczyszyn, Gdańsk 2004, c. 649-670.

21 Ф. Арьес, Человек перед лицом смерти, пер. В. К. Ронин, Москва 1992, с. 506. 
ла чем-то неприличным 22 , а также немецкого философа Эрнста Блоха, по мнению которого, „о смерти не хотят слышать, не хотят на нее смотреть"23. Проблему смерти и умирания вытесняют из массового сознания, чтобы уберечь общество перед непреодолимой фрустрацией ${ }^{24}$.

На противоположном полюсе замечается увлечение, даже очарование процессом умирания, убийства и трупами, которое проявляется в массовой культуре $^{25}$. На эту бинарную позицию обращает внимание Михаил Ямпольский: „Очевидна тенденция скрыть смерть, удалить ее из поля нашего зрения. С другой стороны, сильна тенденция эксгибировать смерть, сделать ее непременным мотивом современных зрелищ"26. В свою очередь, Андрей Демичев утверждает, что русской культуре - не только массовой - свойственно „центрирование и визуализация телесно идентифицированной смерти" 27 , что проявляется в похоронных обрядах, литературных сюжетах русской классики и, наконец, существовании мавзолея с мертвым телом Ленина на центральной площади страны.

В романах Шишкина отражается установка на сокрытие умирающих, медикализацию смерти, обманывание умирающих. Способ жизни, работа, отнимающая значительное количество времени, с одной стороны, и забота об уходящем из жизни близком, с другой, - заставляют нас оставлять умирающих в больнице, даже если они не подлежат лечению. В произведениях Взятие Измаила, Письмовник и Пальто с хлястиком представлен сюжет о больной раком матери, пребывающей последние дни своей жизни в больнице. Во Взятии Измаила и в рассказе Пальто с хлястиком - сю-

22 См.: G. Gorer, Pornografia śmierci, пер. I. Sieradzki, „Teksty: teoria literatury, krytyka, interpretacja” 1979, № 3, c. 197-203.

${ }^{23}$ Цит. за: S. Kaczmarek, Rozważania o życiu ludzkim, Warszawa 1979, c. 117.

24 J. Kwaśniewski, Tabu śmierci. Dlaczego powstało, dlaczego gaśnie, http://jacek.kwasniewski.eu.org/strona5_inne_teksty.html [дата обращения: 30.10.2017]. См. также: M. Přridalová, Proč je moderní smrt tabu?, „Sociologický časopis” 1998, № 3, c. 347-361.

25 В качестве примера можно привести ряд телесериалов: Морская полиция (NCIS), CSI Meсто преступления (и его клоны), Детектив Раш, Закон и порядок. Преступное намерение, Кости, Autopsy и др. Яцек Новаковски называет кинофильмы, в которых жестокое причинение смерти и натуралистические образы изуродованных мертвых тел занимают центральное место сюжета. J. Nowakowski, Filmowe lekcje anatomii, [в:] Strategie śmierci formy umierania. Świadectwa literackie i kulturoznawcze, ред. W. J. Burszta, Warszawa 2004, c. 127-138. Современным вариантом реалистического изображения мотива dance macabre можно считать новейший готицизм в рамках течения сплэттер. См., напр.: А. E. Kubiak, Współczesny gotycyzm nurtu gore, [в:] еe же, Inne śmierci, Kraków 2014, с. 177-186. Об интересе к мертвому телу свидетельствует также огромный успех выставок пластинированных трупов Гунтера фон Хагенса. См., напр.: M. Bracki, Figuracje śmierci i ciała - trup jako kulturowy autokomentarz, [в:] Strategie śmierci - formy umierania. Świadectwa literackie i kulturoznawcze, ред. W. J. Burszta, Warszawa 2004, с. 117-125

26 М. Ямпольский, Смерть в кино, „Искусство кино” 1991, № 9, с. 54.

27 А. Демичев, Dеатинейленд, [в:] Фигуры Танатоса. Искусство умирания, ред. А. В. Демичев, М. С. Уваров, Санкт-Петербург 1998, с. 55. 
жет явно автобиографичен, в Письмовнике эта история приписана главной героине и показана в развернутом, более детальном варианте. Умирающей матери Саши требуется постоянный уход, и потому она лежит в больнице. Дочь каждый день навещает маму, присутствует при ее умирании, несмотря на то, что забота о матери отнимает у нее много психических сил. Она знает, что нет уже спасения от этой болезни - врач проинформировал ее, что состояние матери безнадежно, и это последние дни жизни. Однако после разговора с врачом героиня утешает мать, что та идет на поправку, что скоро выздоровеет. В данном сюжете писатель фиксирует современное отношение к умиранию - страх, неловкость в контакте с уходящим из жизни, недоговоренность и обман в разговорах с ним ${ }^{28}$. Скрывая правду о приближении последнего часа, современный человек не позволяет умирающему завершить все земные дела: попрощаться с близкими, передать свою последнюю волю. Саша уверена в том, что обман облегчает последние дни жизни матери, и с удивлением узнает от маминой подруги, что мать прекрасно знает о надвигающейся смерти. И тем не менее Саша не решается честно говорить с матерью 29.

В выше представленной истории содержатся также описания изменений, каким подвергается больное тело женщины, и реакция организма на разных стадиях болезни, некую физиологию умирания, например: „В последний раз, когда я ее видела, ей было очень плохо, она стонала, во рту пересохло, капли пота высыпали на лбу. Рвота даже от глотка чая. Дыхание было хриплое, затрудненное. Это опухоли выталкивали ее из тела" [П, c. 344].

Несмотря на частые визиты Саши в больницу, мать умирает в одиночестве, что навсегда останется на совести дочери:

Мы опоздали, мамы уже не было.

У меня было чувство, что случилось непоправимое. Не потому, что мама ушла, за время ее болезни я была к этому уже готова.

Все эти месяцы я испытывала чувство вины перед ней, сама не знаю за что, может быть, за то, что она уходит, а я остаюсь. И мне казалось, что это чувство пройдет, если в минуту смерти я буду рядом. Мне хотелось быть с ней и держать ее за руку. А я опоздала.

28 Ф. Арьес в рассуждениях о „смерти перевернутой” обращает внимание на „благонамеренную игру” с умирающим, чтобы утаить правду о его состоянии. Ф. Арьес, Человек перед лииом смерти..., с. 512-513.

29 Джон Хинтон утверждает, однако, что такая мистификация в отношениях больнойврач может принести пользу умирающему, так как больной избегает таким образом огорчительных переживаний. J. Hinton, Śmierć i lekarz, [в:] А. Toynbee i in., Człowiek wobec śmierci, пер. D. Petsch, Warszawa 1973, c. 57-59. См. также: J. Bréhant, Sidła ktamstwa i niebezpieczeństwo samobójstwa, [в:] еe же, Thanatos. Chory i lekarz w obliczu śmierci, пер. U. Sudolska, Warszawa 1993, c. 64-66. 
Она была все время болезни со мной, а умерла в одиночку. Мне было особенно больно именно от этого [П, с. 345-346].

Отсутствие в момент смерти близкого становится для семьи особенно тяжелым переживанием, которое возвращается в мучительных воспоминаниях ${ }^{30}$. Смерть в больнице зачастую является смертью одинокой, для перегруженного работой персонала умирающий является только медицинским случаем $^{31}$, он лишен автономии, возможности переживать последний час. Одиночество становится тяжелее, когда человеку не дают права на получение информации о состоянии своего здоровья, вследствие чего он не может принимать решения, остается безвольным и пассивным ${ }^{32}$.

После потери матери героиня Письмовника считает очень важным пережить смерть отца по-другому. Поэтому Саша сопровождает папу в последние минуты и наблюдает процесс ухода его из жизни:

Папа так дышал, что кровать под ним ходила ходуном. Говорить он уже не мог и не отрывал от меня просящих глаз. Я знала, о чем он просит.

Мне захотелось обнять его, я прилегла рядом на кровать, прижалась к нему, все время смотрела ему в глаза. Взгляд его изменился. Он глядел на меня, но глаза уже не просили. В них было какое-то удивление.

Он уходил. Он еще был со мной, но уже заглянул туда. Он остановился, помедлил на какое-то мгновение на черте. Увидел то, что мне из этой комнаты не было видно. [...]

Я все это пишу для того, чтобы объяснить удивительное ощущение: я держала его за руку в ту минуту, наверно, самую важную в жизни человека, и чувствовала себя счастливой [П, с. 394-395].

Отсутствие честного, открытого подхода к теме умирания и смерти в наше время характерно не только по отношению к другим. Современный человек не хочет думать даже о собственной смерти. Жить, помня о смерти, memento mori - мысль, пронизывающая всю нашу культурную традицию, но сегодня эта идея неактуальна. Большинство предпочитает не думать и не говорить о собственной смерти, молодежь совсем равнодушна по отношению к ней ${ }^{33}$. Раньше люди хотели важно подготовиться к смерти, успеть

30 J. Bréhant, Stres, [в:] еe же, Thanatos..., c. 160-162.

${ }^{31}$ См. напр.: M. Wilson, Zdrowie, postawy $i$ wartości, пер. H. Bortnowska, [в:] Sens choroby, sens śmierci, sens życia, ред. H. Bortnowska, Kraków 1984, c. 32-52; R. G. Twycross, Lekarz wobec umierajacego, пер. H. Bortnowska, [в:] Sens choroby, sens śmierci, sens życia, ред. H. Bortnowska, Kraków 1984, c. 257-274; K. Szewczyk, Lęk, nicość i respirator. Wzorce śmierci w nowożytnej cywilizacji Zachodu, [в:] Umierać bez lęku. Wstęp do bioetyki kulturowej, ред. M. Gałuszka, K. Szewczyk, Warszawa-Łódź 1996, c. 14-62; P. Polewski, Śmierć w hospicjum powrót do korzeni czy nowy paradygmat umierania?, „Okolice. Kwartalnik Etnologiczny” 2005, № 3-4 (Śmierć: obrazy, ikony, metafory), c. 15-36.

32 M. Vovelle, Pod znakiem ,śmierci tabu”..., c. 667. См. также: J. Czarny, Osoba ludzka $w$ umieraniu i śmierci. (Ujęcie personalistyczne), [в:] Moralny wymiar choroby, cierpienia i śmierci, ред. В. Płonka-Syroka, Wrocław 1999, c. 25-32.

33 Там же, с. 653-655. 
довести до конца самые важные дела, попрощаться с близкими, очистить свою душу перед кончиной. В связи с этим с давних времен существуют молитвы от внезапной смерти ${ }^{34}$ и за умерших скоропостижной смертью, кому не было дано закончить свои земные дела.

Писатель отображает, как сегодня людей ужасает мысль об умирании. Если раньше боялись умереть внезапно, то сегодня страшатся умирания в полном сознании, связанного с переживанием физической боли и психических страданий. Идеалом смерти становится смерть скоропостижная. Такую смерть описывает Володя в Письмовнике:

Сашенька, я тут видел идеальную смерть. Человек - молодой, красивый, белозубый $[. .$.$] - исчез моментально. Снаряд попал прямо в него. В сам момент взрыва$ меня там не было, но я потом видел его руку, закинутую на макушку дерева.

Это мой идеал [П, с. 201].

Смерть скрывают, о ней умалчивают, к ней не подготавливают детей. В рассказе Гул затих... (2016) повествователь вспоминает, что когда умирал его дедушка, после ухода врача его отправили в магазин. Ему не сказали, что дедушка при смерти, не посоветовали попрощаться с ним, а под каким-то предлогом отправили из дома, чтобы он не присутствовал при его кончине:

Меня послали в магазин на станцию за носками. Перед тем как бежать в магазин, я зашел к дедушке. В комнате никого больше не было.

Деда трясло, кровать ходила ходуном. Лоб сверкал от пота. Руки дергались. Он скосил желтые помутневшие глаза и смотрел на меня. Хотел что-то мне сказать, но вместо слов его горло выдало какую-то странную трель. Так под эту трель я и ушел. Помню, как бежал за этими дурацкими носками. Когда вернулся минут через двадцать, дедушка уже умер. Наверно, за носками меня специально послали, чтобы я не видел смерти. Думали, пока я туда, пока обратно, много времени пройдет. А я мчался что есть мочи. Но сам момент смерти я действительно пропустил ${ }^{35}$.

Описания телесных страданий, сопутствующих умиранию, сведены в Письмовнике к констатации их смысла: „Говорили с ним о маме, о том, как тяжело ей было умирать. - Ты, Зайка, еще маленькая и ничего в этой жизни не понимаешь! Болезни необходимы — они помогают! Когда такие мучения, то не так страшно уходить” [П, с. 349].

Похожую мысль находим и в других произведениях, например, в рассказе Пальто с хлястиком рассказчик, вспоминая маму, пишет о „тихой смерти, которую она так ждала, чтобы отпустили боли" 36 . Об облегчении, которое приносит смерть, свидетельствует также спокойствие мертвого тела:

34 В православной церкви это, например, молитва Святой Великомученице Варваре или Преподобному Онуфрию Великому.

35 М. Шишкин, Гул затих..., [в:] его же, Пальто с хлястиком. Короткая проза..., с. 277.

${ }^{36}$ М. Шишкин, Пальто..., с. 21. 
Няня в последние недели сильно страдала. Стала страшная, сильно исхудала, лицо, шея - все в каких-то обвисших морщинах. [...] За ночь покойница преобразилась, разгладились все морщины, как будто и не было страшной болезни [BВ, с. 21]; Лицо у нее впервые за много месяцев стало спокойное, умиротворенное. Отмучилась [П, c. 346]; Перед похоронами меня поразили ее успокоившиеся руки в гробу [П, с. 170]; Папа лежал в гробу, сложив руки, как паинька. Я гладила его спокойную грудь, которая не ходила больше ходуном, как в последние минуты перед смертью [П, с. 379].

Лаконичное описание умирания человека содержится в романе Письмовник: „Стал рассказывать, как делал наброски с умиравшей матери. Говорит, что первохолст - это лицо человека, мимика. Потом тело. Потом уже камень” [П, с. 127]. Здесь визуальная репрезентация трех этапов, связанных с уходом из жизни: внимание присутствующего сосредоточено на лице и мимике, еще свидетельствующих о жизни, на следующей картине - это тело, по-видимому, мертвое, неподвижное, но еще недавно принадлежавшее живому человеку и, наконец, надгробный памятник, являющийся доказательством стремления людей освоить смерть — „объективируя в надгробном памятнике свое восприятие-представление о смерти, живущие как бы стремятся снять ее невидимость, ужас, приблизить к себе живому, породниться с нею. Памятник становится проводником-стимулом к иллюзии живого о присутствии мертвого в живом, укрепляет эту иллюзию" 37 .

Образы кончины в прозе Шишкина не ограничиваются описанием умирания вследствие болезни. Довольно часто здесь встречаются картины насильственной смерти: убийств, казни, гибели на войне. Они, как правило, шокируют в силу своего натурализма и представленной жестокости. По мнению Романа Красильникова, реалистичное и натуралистичное изображение смерти противопоставлено романтическому не только в значении ирреального, но и возвышенного. Переход смерти из сферы бытийной в бытовую, из возвышенной в низменную лишает ее осмысленности ${ }^{38}$.

Подобную тенденцию можно заметить в произведениях Шишкина, когда образы насильственной смерти не сопровождаются онтологической рефлексией. В романе Взятие Измаила адвокат, защищающий молодую женщину, утопившую новорожденного ребенка, в своей речи приводит длинную историю ритуального детоубийства в разных культурах и эпохах, безнаказанного и часто поощрявшегося тогдашними мыслителями и предводителями:

Современные люди, такие же, как мы с вами, отличаясь лишь цветом кожи, душат, режут, удавливают, топят, сжигают своих младенцев, и это не считается никаким преступлением. На островах Фиджи до сих пор пожирают своих дитятей - почитайте Bode или, на худой конец, Kohler'a. Тот описывает, как на его глазах свертывали новорожденным головы, продавливали темя пальцем. [...] На острове Ниасе новорожденно-

37 С. Тесля, Кладбище как образ жизни, [в:] Memento vivere, или помни о смерти, ред. В. Л. Рабинович и М. С. Уваров, Москва 2006, с. 299.

38 Р. Красильников, Танатологические мотивы..., с. 333-334. 
го помещают в мешок и вешают на дерево в лесу. У американских индейцев в каждое ухо ребенку заколачивают по горящему углю, а труп бросают в костер [ВИ, с. 105-106].

Свою тираду адвокат заканчивает констатацией, что если бы соблюдать заповедь „Не убий”, то наша цивилизация была бы совсем другой, так как уже с самых давних времен убийства определяли вектор развития всех наций и культур:

А тут нам хотят, поставив все с ног на голову, провозгласить нездешний завет не убий! Вот и мой уважаемый оппонент среди многих преувеличений высказал эту бесспорную, как ему кажется, истину. Да как же не убивать?! Представьте себе только на минуту — Каин не убивал Авеля! И тогда получается, что ничего не было: ни Юлия Цезаря, ни Наполеона, ни Сикстинской мадонны, ни Аппассионаты, ни Шекспира, ни Гете, ни „Войны и мира”, ни „Преступления и наказания”! Ничего! А вы талдычите свое: не убий! Иппонийцы, опомнитесь! [ВИ, с. 107].

Этот апофеоз убийства, высказанный в защиту подсудимой, является на самом деле довольно коварным, но в нем подчеркивается двойная природа преступления, зла. Адвокат, обращаясь к иппонийцам, выступает против учений Блаженного Августина, верующего в победу мира Божьего, но также обращает внимание на факт, что зло, уничтожая людей и божественное начало в них становится плодородной почвой для искусства. Такое замечание можно, в свою очередь, рассматривать как ироническую оценку, данную автором нашей цивилизации.

Образы смерти, наступившей вследствие неестественных причин, в прозе автора Письмовника связаны именно с криминальными убийствами, но чаще всего с войнами, которые Шишкин как пацифист не считает оправданием для убийства. В обоих случаях жертвы представлены писателем натуралистично, с обращением особого внимания на детали, например:

Тело было еще теплым. Кожа, как выяснилось при осмотре, во многих местах содрана - явное следствие усилий, с какими труп заталкивали в дымоход, а потом выволакивали оттуда. Лицо страшно исцарапано, на шее сине-багровые подтеки и глубокие следы ногтей, словно человека душили. [...] там наткнулись на мертвую старуху - ее так хватили бритвой, что при попытке поднять труп голова отвалилась. И тело, и лицо были изуродованы, особенно тело, в нем не сохранилось ничего человеческого [ВВ, с. 48].

С помощью детальной дескрипции военных жертв писатель разрушает миф о героической смерти. Описываемые тела изуродованы, неполны, утеряно то важное, что свидетельствует о личности. Особенно много таких описаний в романе Письмовник, герой которого - участник Ихэтуаньского восстания - делится в письмах своими впечатлениями и рассуждениями. Сначала описания лишены резких подробностей, и герой пополняет их информацией о своих переживаниях: „Сашка, никогда не забуду, как все притихли, увидев в первый раз проплывшее мимо мертвое тело, совсем рядом с бортом, раздувшееся, лицом вниз, даже не было понятно, мужчина это или женщина — с седой косой” [П, с. 111]. 
Впоследствии описания приобретают натуралистический характер они насыщены деталями и объективны. Молодой солдат фиксирует в письмах свои наблюдения: „после разрыва снаряда целыми остались только плечи с руками и голова, а все остальное разлетелось” [П, с. 136]; „увидел собаку с отгрызенной человеческой кистью в зубах” [П, с. 153]; „Руки и ноги как будто отсечены. Их нет! Сапог с остатком ноги валяется рядом” [П, с. 306]; „кисти рук будто пропущены через мясорубку. Беру за плечи, пытаюсь приподнять. Его тело легко поддается ко мне, а затылок остается на траве” [П, с. 306]; „Рядом лежали еще неубранные тела убитых китайских солдат, которых уже объедали мухи и собаки" [П, с. 316].

В повествование романа Венерин волос в форме вымышленного дневника певицы Изабеллы Юрьевой вплетены замечания о событиях и жертвах первой мировой войны: „На рассвете страшный взрыв сотрясает весь город. Это снаряд попал в столовую завода «Аксай» [...] Погибает много людей - кто-то рассказывает, что видели на деревьях куски тел и одежды" [BB, c. 126]. В другой сюжетной линии, повествующей о войне в Чечне, также приводятся натуралистические описания раненых и убитых, например: „Тут выстрелы — и он уже ползет обратно с распоротым животом, кишки волокутся - в соломе, в говне. Там и умер. Я сижу рядом и вижу, как кровь смешивается с лужею воды под ним" [ВВ, с. 299].

В свою очередь, в произведении Взятие Измаила самым ярким примером такого описания пострадавших является фрагмент воспоминаний известного хореографа и танцора Сергея Лифаря, относящийся к событиям гражданской войны в Киеве:

Вбежав в покинутый застенок, мы увидели только изуродованные и еще теплые трупы - одни как попало брошенные, другие как попало зарытые. Но было нечто гораздо страшнее трупов: стены, забрызганные еще влажными мозгами, целые ковры густой крови на бетонном полу с устроенными стоками для крови... [ВИ, с. 341].

С военными действиями связаны также образы казней. Автобиографический герой Венериного волоса показывает своим гостям снятый чеченцами фильм: „Старик спокойно крестится в камеру [...] Ему отрубают голову. Камера показывает в первую секунду не голову, а шею — крупно - она толстая, наверно 45-го размера, и вдруг сокращается в кулак, и из нее выпирает горло и льется черная кровь” [BВ, с. 240].

Володя - герой Письмовника - поражен сценой казни молодого китайца, участвовавшего в боксерском восстании:

Сашенька, я думал, его расстреляют, но сипаи отрубили ему голову. [...]

Я хотел заставить себя смотреть на это, но не смог, в тот самый момент закрыл глаза. Только слышал звук. Ты знаешь, это похоже на звук садовых ножниц. Потом открыл глаза и увидел его голову на земле. Сколько раз видел на разных картинах отрезанные головы, например, на блюде, излюбленный художниками сюжет - в этом было ужасное, но и возвышенное, красивое. А тут передо мной валялось что-то ма- 
ленькое, измазанное черной кровью, облепленное песком. Исковерканный рот с прикушенным языком, закатившийся глаз. Тело без головы какое-то невозможное, куцее. Из шеи этого тела лилась темная струйка [П, с. 183-184].

Повествователь обращает здесь внимание на факт, что в изображении смерти и мертвого тела, как правило, сочетается жуткое и возвышенное. Как ни странно, эти, казалось бы, противоположные определения в случае мортальных образов оказываются близки: „это даже не пара, не бинарная конструкция оппозиционных представлений, а описывающее, точнее, стремящееся описать визуальный опыт, априорно предвкушаемый как эстетизированный запрос желанного/нежелаемого"39. Обыденность страшных сцен, дикой жестокости военного времени лишает смерть ее возвышенности.

Детальная визуализация военных жертв дополняется ольфакторными элементами ${ }^{40}$, которые, как правило, „прочно связаны с эмоциями"41 и усугубляют ужас описаний. Тот же герой Письмовника, наблюдая за свиньями, копавшимися в чем-то сожженном, вдруг осознает, что это обугленные трупы: „Там была черная истлевшая рука, и я видел, как от толчка пальцы осыпались. И от всего этого шла ужасная вонь” [П, с. 317]. Такой же отвратительный запах он чувствует, наблюдая за уборкой трупов с поля: „Поднялось солнце, начало палить, и вонь от мертвецов стала нестерпимой. Крестьяне работали, заткнув себе ноздри пучками травы” [П, с. 316].

Мертвые тела не обладают индивидуальными чертами, и Володя обнаруживает их удивительное сходство: „Знаешь, что в мертвых удивляет? Что они все становятся похожи друг на друга. При жизни были разные, а потом у всех глаза одинаковые - зрачки глаз тусклые, кожа восковая, а рты почему-то всегда открыты" [П, с. 254-255].

Мертвецы, с уже присущими им свойствами, скорее всего, не человека, а биологического материала, подлежат разложению. Изображая труп, Шишкин особое внимание уделяет ольфакторному аспекту, и нередко запах становится самостоятельным признаком смерти 42 :

И запах одинаковый. Не запах, конечно, а вонь. Смрад. Самый противный запах на земле.

Ты знаешь, сколько я в жизни видел мертвых рыб, птиц, зверей, но такой вони, как от человеческих трупов, никогда не было [П, с. 254].

Приведенные выше жуткие картины изуродованных, разлагающихся мертвых тел на поле сражений свидетельствуют об авторской позиции по отношению к войне. Шишкин разоблачает миф о прекрасной войне, о бла-

39 В. А. Мазин, Междужутким и возвышенным, [в:] Фигуры Танатоса..., с. 169.

40 См.: L. Szewczenko, Ольфакиионный код прочтения чувственных состояний в „Письмовнике” Михаила Шишкина, ,Slavica Wratislaviensia” № 161, 2015, c. 105-106.

${ }^{41}$ С. Т. Махлина, Ольфакция, [в:] ее же, Словарь по семиотике культуры, Санкт-Петербург 2009, с. 399.

42 Cм.: L.-V. Thomas, Trup, пер. K. Kocjan, Łódź 1980, c. 71. 
городной, героической смерти в бою ${ }^{43}$. Смерть является здесь анонимной неизвестно, кто убивает и кто гибнет, деперсонифицированный механизм войны уничтожает свои жертвы, которые остаются лишь неизвестными солдатами, а не героями с прославленными именами ${ }^{44}$.

Темой танатологической рефлексии Шишкина является не только процесс умирания и убийства, но и комплекс вопросов, связанных с мертвым телом, к которым можно отнести, помимо описания покойников и мертвых тел, изуродованных разного рода насилием, представление собственно процессов разложения мертвого тела и в конце - похоронных обрядов.

По отношению к трупам в современной культуре также намечаются два противоположных полюса - очарование и отвращение. Жак Линн Фолтин подчеркивает:

мы колеблемся в своем отношении к мертвому телу. Мы его используем и отвергаем, демонстрируем и прячем, выставляем напоказ и маскируем, почитаем и оскверняем, считаем его чем-то забавным и чем-то торжественным, сакральным и профанным. Оно привлекает и отталкивает нас. Мы насытили мертвое тело напряжением парадокса, сделали его необычным и банальным, полезным и бесполезным ${ }^{45}$.

В прозе Шишкина описания мертвых тел появляются довольно часто не только в связи с военной тематикой, причем неоднократно натуралистическая детализация дескрипции может шокировать, но и в содержании произведений эти образы находят свое обоснование, хотя не являются сюжетообразующими элементами. В романе Взятие Измаила, в котором повествователь-герой работает следователем, приводится обширный фрагмент (на несколько страниц) учебника патоморфологии конца XIX века, предназначенного для следователей и полицейских врачей того времени. Здесь объясняется способ определения времени кончины и ее причин с помощью различных симптомов, например, температуры тела, окоченения, степени разложения в разных условиях:

Важным фактором является и появление так называемых трупных пятен, которые, вы не поверите, передвигаются, странствуют, если тело перевернуть, но спустя 5-6 часов путешествие пятен прекращается. Нахождением куколок мух можно также определить более или менее точное время наступления смерти. Сначала поедают тело малые, затем средние и только тогда уже большие мухи. Рекомендуется собирать эти куколки в банки для удостоверения искомого момента, так как нужно торопиться, потому что начинается гниение плоти. Самый благоприятный температурный режим для этого процесса $37^{\circ}$, при температурах выше $60^{\circ}$ и ниже $0^{\circ}$ гниение невозможно.

43 См.: К. Л. Харт Ниббриг, Эстетика смерти, пер. А. Белобратова, Санкт-Петербург 2005, c. $179-182$.

${ }^{44}$ Cp.: A. Makowski, Śmierć na polu walki, [в:] Mare Integrans. Studia nad dziejami wybrzeży Morza Bałtyckiego, t. XII ,'Śmierć w dziejach człowieka”. Współczesność, pед. M. Franz, К. Kościelniak, S. Pilarczyk, Toruń 2016, c. 29-31.

45 Ж. Л. Фолтин, Популярные мертвые и сексуальные мертвые: массовая культура, криминалистическая экспертиза и восстание мертвецов, пер. Ю. Колошенко, Д. Перегудов, „Археология русской смерти” 2017, № 1 (4), с. 100. 
Здесь картину определяет окружающая среда - гниение тела открытого в течение 2-3 недель равно гниению тела, закрытого от воздуха, в течение шести месяцев. Труп в воде гниет в восемь раз медленнее трупа на воздухе. Легче всего загнивает мозг новорожденного. Небеременная матка гниет медленнее всего. Позеленение наступает через 4-5 дней первоначально у пахов. Гнилость выражается в появлении специфического трупного запаха [ВИ, с. 63-64].

К описанию мертвого тела Шишкин прибегает также в сценах вскрытия трупа молодой девушки „с отпиленным поверх бровей черепом” [ВИ, с. 182] и эксгумации, причем ожидание наблюдателя увидеть разложившиеся останки не оправдывается:

Не знаю, что я ожидал увидеть - страшную картину разложения, полуистлевшую мумию, скелет, одним словом, я был готов встретиться с чем-то уже нечеловеческим, что имело бы к ней лишь опосредованное отношение - и вдруг перед моими глазами, когда крышку сняли и аккуратно положили сбоку, оказалась моя мама, почти такая же, какая она была тогда, в день похорон, только лицо еще больше осунулось, вылез нос, впали щеки, ногти почернели, а цвет кожи стал совсем желтым [ВИ, с. 99].

Круг танатологических мотивов в прозе Шишкина охватывает также культурологический и психологический аспекты отношения к мертвому телу. Самой важной темой являются здесь похоронные обряды и обычаи. В произведениях автора Венериного волоса содержится обширная информация о похоронном ритуале в современной России, причем нет единого описания, охватывающего целый обряд, а информация об отдельных его этапах разбросана в разных сюжетных линиях его рассказов и романов. Итак, писатель приводит сцены приготовления мертвеца к похоронам обмывания, одевания, посмертного макияжа, украшения в гробу, причем можно заметить существенные изменения в подходе к этим действиям за последние десятилетия: если раньше этим занимались оставшиеся близкие, в том числе соседи (особенно в деревне), то сейчас исчезло коллективное переживание смерти, и для приготовления тела усопшего к погребению созданы фирмы ритуальных услуг. В некоторых произведениях Шишкина изображены разные элементы ритуала самих похорон и кремации как последнего прощания с телом близкого человека. Они относятся и к мирному времени, и к военным условиям, когда сложно соблюдать традицию, но надо относится к телам погибших с уважением: „Не было досок для гробов — хоронили в мешках. [...] Закопали их в полуверсте от лагеря на пригорке. Сколотили один на всех крест, сунули его в сухую глину. Закопали неглубоко - не было сил на солнцепеке копать глубокую яму” [П, с. 136].

Писатель представляет также ситуацию отсутствия тела после смерти - в романе Венерин волос приводится история, как во время бомбардировки снаряд упал на маленькую девочку и ее не стало. Такое двойное отсутствие особенно трагично - погибший отсутствует и в мире живых 
и среди умерших. Для процесса прощания и переживания траура важен ритуал похорон, и в описываемом случае захоронили как субститут тела зимнюю шубку ${ }^{46}$.

Танатологическая тематика в произведениях Шишкина пополнена также сведениями о похоронных обрядах и способах захоронения в разных культурах. Писатель обогатил свои тексты информацией об отношении к покойникам и проведении погребальных ритуалов, в частности, в Древнем Египте, Древней Персии, в мусульманской традиции, в разных провинциях Китая, объясняя специфику обычаев местной религией и верованиями.

Отношение к мертвому телу Шишкин показывает и в психологическом аспекте. Он фиксирует странные, противоречивые эмоции, испытываемые по отношению к покойникам, основанные на когнитивном диссонансе „человек-предмет". Труп является пустым знаком, существующим без феноменального субъекта, „является присутствием, отсылающим к отсутствию”, Писатель ставит вопрос, когда мы в состоянии признать мертвое тело человеком, а когда оно становится для нас только предметом. Шишкин иллюстрирует проблему реификации человеческого тела и отношения к нему, ставя своих героев в ситуации ритуального прощания на похоронах: „Когда перекладывали тело в гроб, я поднимал его за бедро - дедушкино тело стало твердым и звонким, будто это не человек, а фигура изо льда" 48 ; „поцеловать то, что там лежало, так и не смог”,49; „Я прикоснулся губами к маминому лбу. Мне показалось, что я дотронулся до холодной железной трубы" [ВИ, с. 90].

Этот диссонанс появляется и у героини Письмовника во время похорон матери:

У меня было странное ощущение, что мы хороним не мою маму, а кого-то еще.

Я знала, что это не она, что это тело в гробу — пустое, что мама не может лежать заваленная снегом в неудобном холодном ящике с голыми посиневшими руками на ввалившейся груди, но сходство этой мертвой женщины в гробу с моей мамой в какие-то минуты становилось нестерпимым, и у меня начинали литься слезы [П, c. 347-348].

Похожие ощущения испытывает герой Взятия Измаила: „В гробу лежала - как чужая. Смотрю на нее и думаю: нет, это не моя Маша, это ктото еще" [ВИ, с. 32].

В таком отношении появляется фрейдовское толкование психологии страха смерти. Фрейд пытается вскрыть этот механизм, определяя его место в области между я и сверх-я. Он утверждает, что по сути дела в глуби-

\footnotetext{
${ }^{46}$ Cp. L.-V. Thomas, Trup..., c. 44-45.

47 Там же, с. 43.

48 М. Шишкин, Гул затих..., с. 278.

49 Там же.
} 
не души мы не верим в собственную смерть. Страх, испытываемый нами, противоречит бессознательной уверенности в собственное бессмертие. Он происходит от чувства вины, осознание которой следует из двойственного чувства по отношению к покойнику. Мертвое тело по инерции обладает интенцией жизненного участия, но, с другой стороны, уже стало вещью, требующей своего укрытия в небытии, что порождает страх смерти из идентификации с покойным ${ }^{50}$.

В творчестве автора Письмовника танатологические мотивы главным образом можно отнести к числу свободных мотивов (по классификации Бориса Томашевского $\left.{ }^{51}\right)$, не образующих направления развития сюжета, однако сложно определить степень их влияния на „цельность причинно-временного хода событий”52, так как в произведениях Шишкина связность повествования и линейность сюжета вообще отсутствуют ${ }^{53}$. Они представляют собой собрание различных историй, коллекцию рассказов, не связанных друг с другом, но именно таким образом отражающих мир в его разнообразии 54 . Эта нарративная стратегия не похожа на поэтику прозы XIX века, когда последовательность мотивов и событий, в том числе и мотивов, связанных со смертью, обусловливала в большей или меньшей степени ход действия ${ }^{55}$.

Это обилие образов, отражающих смерть тела и его описание после кончины, может создать впечатление, что в творчестве Михаила Шишкина преобладает некрофильная тенденция. Такая оценка ошибочна, так как в его прозе можно заметить равновесие между элементами танатологическими и жизнеутверждающими. Сцены смерти и мертвых тел, как правило, вводятся в сюжеты шишкинских произведений как нечто естественное, неотделимое от жизни, создающее со светлыми, радостными элементами гармоничное целое. Жестокость, ужас, грусть, вызванные смертью, уравновешиваются чаще всего любовью, теплыми отношениями. Такое сочетание обнаруживаем в Письмовнике, где гибель на войне переплетается с любовью, нежностью, которой пропитаны письма Володи; во Взятии Измаила убийства, расследуемые Александром Васильевичем, чередуются с историей его родительской любви и заботы о больной дочери; в Венерином волосе

${ }^{50}$ Z. Freud, Wstęp do psychoanalizy, пep. S. Kempnerówna, W. Zaniewicki, Warszawa 1982, c. $383-398$.

51 Б. Томашевский, Теория литературы. Поэтика, Москва 2003, с. 183-184.

52 Там же, с. 183.

53 В качестве исключения можно назвать первый роман Михаила Шишкина Bcех ожидает одна ночь, другое его заглавие - Записки Ларионова (1993).

54 О коллекции как о художественном приеме пишут, например: B. Frydryczak, Świat jako kolekcja. Próba analizy estetycznej natury nowoczesności, Poznań 2002; T. Misiak, O estetycznym kolekcjonowaniu świata, „Sztuka i Filozofia” № 2223, 2003, c. 309-316.

55 См.: А. Е. Козлов, Сюжет о мертвом теле в русской литературе ХІХ века. Статья 1, „Сюжетология и сюжетография” 2015, № 1, с. 147-157; его же, Сюжет о мертвом теле в русской литературе XIX века. Статья 2, „Сюжетология и сюжетография” 2015, № 2, c. 91-100. 
ужасы первой мировой войны и войны в Чечне представлены параллельно с любовными сюжетами.

Мотивы мертвого тела писатель вводит по принципу контраста со сценами, вызывающими приятные ощущения, мысли, воспоминания. Например, в рассказе Гул затих эпизод смерти дедушки включается в историю встречи с любимой девушкой; приготовление же тела к похоронам ассоциируется со вкусом яблок:

Обмывать тело позвали помогать соседку.

Деда положили на стол на террасе. Она не отапливалась. На террасе складывали осенью яблоки в ящиках. После морозов они чернели. Я ужасно любил замороженные яблоки. Когда оттаивали, они растекались во рту, сочные, сладкие ${ }^{56}$.

В автобиографическом сюжете Венериного волоса повествователь совмещает в одном воспоминании и мертвое тело сына, и сцену любви:

Сын умер в больнице, после вскрытия привезли в морг вещи, стали одевать, поднял его голову, а та легкая, как спичечный коробок - вынули мозг. От костра по реке сыпь. Так хорошо было после любви лежать на скрученной простыне, есть виноград, смотреть, как ты заплетаешь волосы, как ходит лопатка под кожей, потом как по этой лопатке ударяет заброшенная за спину коса [BB, с. 477-478].

Саша - героиня Письмовника, заботясь об умирающей матери, ухаживает за маленькими сыновьями своей подруги и испытывает семейное счастье.

Мысль о равновесии в жизни и в мире появляется в прозе Шишкина многократно. Например, Изабелла — героиня романа Венерин волос — под влиянием вести о погибших в военных действиях записывает в дневнике: „И чем больше смерти кругом, тем важнее ей противопоставить жизнь, любовь, красоту!” [BВ, с. 351]. В другом месте того же произведения рассказчик вводит метафору рыбы как мира и констатирует: „, ...] внутри рыбы все уравновешено и гармонично - и смертей ровно столько, сколько рождений, а рождений ровно столько же, сколько смертей — ни на одну больше или меньше, и в этой бухгалтерии все всегда сходится и всегда будет сходиться" [ВВ, с. 306].

Такая же рефлексия появляется в Письмовнике:

Назовите всеобщую гармонию хоть фэншуем, хоть уставом, без разницы, главное, что всего в ней с избытком - и жизни, и смерти, а главное, человеческого тепла [П, c.104]; А смерть - это борьба космоса со временем, с нами. Ведь что такое космос? Это ведь по-гречески порядок, красота, гармония. Смерть - это защита всеобщей красоты и гармонии от нас, от нашего хаоса [П, с. 304].

Обезжизненное мертвое тело в религиозной православной традиции окружается почитанием, что связано с одной из основных идей христианства — идеей воскрешения плоти. Православная Церковь исповедует

${ }^{56}$ М. Шишкин, Гул затих..., с. 277. 
не бессмертие души, а именно телесное воскресение 57 . Эта теологическая проблема, обсуждаемая с давних времен философами и праведниками ${ }^{58}$, для большинства людей сводится к вопросу о том, какими будут наши воскресшие тела? Разложение и запах тела ${ }^{59}$ не согласуются с представлением о воскрешении мертвых. Вопрос об этом беспокоит и одного из учеников в романе Венерин волос: „Как же мы восстанем из праха, если наши тела съедят черви, червей съедят птицы, птицы разлетятся по всему миру, и их тоже кто-нибудь съест?" [BВ, с. 174]. Писатель не оставляет этот вопрос без ответа: преподающий Закон Божий отец Константин объяснил:

Если сапожник сошьет сапог, а потом распорет его и один кусок забросит в Африку, другой в Америку, третий в Азию или на Северный полюс, а потом все куски соберет, ему ничего не будет стоить вновь сшить эти части и сделать прежний сапог. И так же вот после нашей смерти, когда тело станет и небом, и землей, и деревьями, и водой, Бог соберет все части воедино [BВ, с. 174-175].

Этот фрагмент представляет собой образную, на уровне детских рассуждений, интерепретацию тех многих мест Ветхого и Нового Завета, где речь идет о всеобщем грядущем воскресении. В Венерином волосе приводится также информация о фреске Луки Синьорелли Воскрешение плоти, которую можно посмотреть в соборе итальянского города Орвието. Писатель и литературный критик Майя Кучерская предлагает читать произведение Шишкина в ключе христианского обещания ${ }^{60}$, ссылаясь также на оформление обложки первого издания романа ${ }^{61}$, но немаловажной подсказкой она считает и эпиграф к роману: „И прах будет призван, и ему будет сказано: «Верни то, что тебе не принадлежит; яви то, что ты сохранял до времени. Ибо словом был создан мир, и словом воскреснем»” (Откровение Варуха, сына Нерии. 4, XLII).

57 См., напр.: Протоиерей Михаил Воробьев, Всеобщее воскресение мертвых. Беседовал Денис Каменщиков, „Православие и современность” 2010, № 9, https:/eparhia-saratov.ru/ Articles/article_old_9498 [дата обращения: 12.06.2017].

58 Эта проблема с давних времен интересовала философов и теологов. См. напр.: R. K. Wilk OSPPE, Śmierć i zmartwychwstanie ciała człowieka, Kraków 2015.

59 Благоухание мертвого тела или останков свидетельтствуют о святости умершего. Федор Достоевский представил эту проблему в Братьях Карамазовых на примере смерти старца Зосимы. Шишкин также затрагивает эту тему в романе Венерин волос в истории о Святом Клименте: „Получатель небесных букв рассказал о мученичестве Клемента жителям Херсонеса, которые ничего об этом уже не знали и не поверили ему. Кирилл тогда поплыл на то место и начал поиски, чтобы убедить их. [...] Ведь что-то должно было доказать, что есть Бог и, значит, нет смерти. Доказать это могло только чудо. И вот в песке чтото сверкнуло, засияло на солнце - ребро. Слепящая белизной кость. Стали копать дальше и нашли голову и все остальное. И еще всех поразило благоухание. А запахи - это ведь язык Бога. И вот эти вкусно пахнувшие кости Кирилл привез в Рим” [ВВ, с. 214].

${ }^{60}$ См.: М. Кучерская, „Бог сохраняет все, особенно - слова...”, „Критическая масса” 2005, № 2, http://magazines.russ.ru/km/2005/2/ku4.html [дата обращения 4.06.2017].

${ }^{61}$ На обложке первого издания романа (издательство Вагриус 2005 год) помещен фрагмент фрески Луки Синьорелли Воскрешение плоти. 


\section{Сам Шишкин в одном из интервью высказал свое мнение о писатель- ском призвании:}

Художник - это тот, кто берет реальность, страшную нашу человеческую жизнь, в которой человека унижают, в которой если есть любовь, то ее затаптывают, предают, в которой никакой справедливости нет, зато смерти много, — и вот художник должен взять на себя весь этот ужас мира, сделать с ним что-то, что и является тайной искусства, и дать мне, как зрителю или читателю, ощущение, что Бог есть, что все существует не просто так, и я, получив это, уйду просветленным с чувством радости и человеческого тепла ${ }^{62}$.

Предложенная Кучерской идея романа вписывается в эту концепцию литературного творчества: писатель, наблюдая все ужасы мира, дает надежду на воскресение, воскресение в слове.

\section{Библиография}

Арьес Ф., Человек перед лиияом смерти, пер. В. К. Ронин, Москва 1992.

Богданов К. А., „,Тела, тела, тела...”: к истории медииинского дискурса в русской литераmype, „Wiener Slawistischer Almanach”, т. 49, 2002.

Гроссман Л., Путь Достоевского, [в:] его же, Собрание сочинений в 5 томах, т. II, Москва 1928.

Демичев А., Deathнейленд, [в:] Фигуры Танатоса. Искусство умирания, ред. А. В. Демичев, М. С. Уваров, Санкт-Петербург 1998.

Иванов С., Шишкин М., Писатель должен ощутить всесилие?, „Контракты.UA” 4.08.2010, http://apps.kontrakty.ua/coffe/17-mikhail-shishkin/32-pisatel-dolzhen-oshhutit-vsesilie. html.

Козлов А. Е., Сюжет о мертвом теле в русской литературе ХІХ века. Статья 1, „Сюжетология и сюжетография" 2015, № 1 .

Козлов А. Е., Сюжет о мертвом теле в русской литературе ХІХ века. Статья 2, „Сюжетология и сюжетография" 2015, № 2.

Красильников Р., Танатологические мотивы в художественной литературе, Москва 2015.

Кучерская М., „Бог сохраняет все, особенно - слова...”, „Критическая масса” 2005, № 2, $\mathrm{http}: / /$ magazines.russ.ru/ $\mathrm{km} / 2005 / 2 / \mathrm{ku} 4 . \mathrm{html}$.

Мазин В. А., Между жутким и возвышенным, [в:] Фигуры Танатоса. Искусство умирания, ред. А. В. Демичев, М. С. Уваров, Санкт-Петербург 1998.

Махлина С. Т., Ольфакиия, [в:] ее же, Словарь по семиотике культуры, Санкт-Петербург 2009.

Протоиерей Михаил Воробьев, Всеобщее воскресение мертвых. Беседовал Денис Каменщикков, „Православие и современность” 2010, № 9, https://eparhia-saratov.ru/Articles/ article_old_9498.

Сартр Ж.-П., Бытие и Ничто, пер. В. И. Колядко, Москва 2000.

Сыродеева А. А., Полифония как приниип иелостности, „Вопросы философии” 2008, № 3.

Тесля С., Кладбище как образ жизни, [в:] Meтеnto vivere, или помни о смерти, ред. В. Л. Рабинович и М. С. Уваров, Москва 2006.

${ }^{62}$ М. Шишкин, „Написать свою Анну Каренину”. Интервью, „9 Канал”, 5.12.2010, http://9tv.co.il/news/2010/12/05/89804.html.

Slavica Wratislaviensia 167, 2018

(C) for this edition by CNS 
Толстая С., Тело как обитель души: славянские народные представления, [в:] Тело в русской культуре. Сборник статей, сост. Г. И. Кабакова и Ф. Конт, Москва 2005.

Фолтин Ж. Л., Популярные мертвые и сексуальные мертвые: массовая культура, криминалистическая экспертиза и восстание мертвецов, пер. Ю. Колошенко, Д. Перегудов, „Археология русской смерти” 2017, № 1 (4).

Харт Ниббриг К. Л., Эстетика смерти, пер. А. Белобратова, Санкт-Петербург 2005.

Цивиян Т., О телесности души в русской литературе (Постановка вопроса и некоторые примеры), „Wiener Slawistischer Almanach” Тело и душа в русской литературе и кульmуре, т. 54, 2004.

Цивьян Т., Отношение к себе и к своему телу в русской модели мира, [в:] Тело в русской культуре. Сборник статей, сост. Г. И. Кабакова, Ф. Конт, Москва 2005.

Шишкин М., „Написать свою Анну Каренину”. Интервью, „9 Канал” 05.12.2010 http://9tv. co.il/news/2010/12/05/89804.html.

Шишкин М., Венерин волос, Москва 2012.

Шишкин М., Взятие Измаила, Москва 2001.

Шишкин М., Пальто с хлястиком. Короткая проза, эссе, Москва 2017.

Шишкин М., Письмовник, Москва 2016.

Ямпольский М., Смерть в кино, „Искусство кино” 1991, № 9.

Bracki M., Figuracje śmierci i ciała — trup jako kulturowy autokomentarz, [в:] Strategie śmierci - formy umierania. Świadectwa literackie i kulturoznawcze, ред. W. J. Burszta, Warszawa 2004.

Bréhant J., Thanatos. Chory i lekarz w obliczu śmierci, пер. U. Sudolska, Warszawa 1993.

Czarny J., Osoba ludzka w umieraniu i śmierci. (Ujęcie personalistyczne), [в:] Moralny wymiar choroby, cierpienia i śmierci, ред. В. Płonka-Syroka, Wrocław 1999.

Freud Z., Wstęp do psychoanalizy, пер. S. Kempnerówna, W. Zaniewicki, Warszawa 1982.

Giddens A., Ciało i świadomość, [в:] его же, Nowoczesność i tożsamość. „Ja” i społeczeństwo w epoce późnej nowoczesności, пер. A. Szulżycka, Warszawa 2002.

Gorer G., Pornografia śmierci, пер. I. Sieradzki, „Teksty: teoria literatury, krytyka, interpretacja” 1979, № 3.

Goutierre M. D., Ludzkie ciało: uwarunkowanie i osoba, [в:] еe же, Człowiek w obliczu własnej śmierci. Absurd czy zbawienie?, пер. A. Kuryś, Kraków 2001.

Gurczyńska-Sady K., Problem ciała i przyszłość ludzkości, czyli na co komu dwudziestowieczna filozofia, „Analiza i Egzystencja” 2011, № 15.

Heidegger M., Śmierć jako fakt biologiczny i jako fenomen egzystencji, пер. M. Skwieciński, [в:] Filozofia egzystencjalna, сост. L. Kołakowski i K. Pomian, Warszawa 1965.

Hinton J., Śmierć i lekarz, [в:] А. Tоуnbeе и др., Człowiek wobec śmierci, пер. D. Petsch, Warszawa 1973.

Kubiak A. E., Współczesny gotycyzm nurtu gore, [в:] ee же, Inne śmierci, Kraków 2014.

Makowski A., Śmierć na polu walki, [в:] Mare Integrans. Studia nad dziejami wybrzeży Morza Bałtyckiego, t. XII „Śmierć w dziejach człowieka”. Współczesność, ред. М. Franz, К. Коścielniak, S. Pilarczyk, Toruń 2016.

Michalski K., Heidegger i filozofia współczesna, Warszawa 1978.

Migasiński J., Percepcja i ciało, [в:] его же, Merleau-Ponty, Warszawa 1995.

Nowakowski J., Filmowe lekcje anatomii, [в:] Strategie śmierci - formy umierania. Świadectwa literackie i kulturoznawcze, ред. W. Ј. Burszta, Warszawa 2004.

Polewski P., Śmierć w hospicjum — powrót do korzeni czy nowy paradygmat umierania?, „Okolice. Kwartalnik Etnologiczny” 2005, № 3-4 (Śmierć: obrazy, ikony, metafory).

Přidalová M., Proč je moderní smrt tabu?, „Sociologický časopis” 1998, № 3.

Szewczenko L., Ольфакциионный код прочтения чувственных состояний в „Письмовнике” Михаила Шишкина, „Slavica Wratislaviensia” № 161, 2015. 
Szewczyk K., Lęk, nicość i respirator. Wzorce śmierci w nowożytnej cywilizacji Zachodu, [в:] Umierać bez lęku. Wstęp do bioetyki kulturowej, pед. М. Gałuszka, K. Szewczyk, Warszawa-Łódź 1996.

Thomas L.-V., Trup, пер. K. Kocjan, Łódź 1980.

Twycross R. G., Lekarz wobec umierającego, пер. H. Bortnowska, [в:] Sens choroby, sens śmierci, sens życia, ред. Н. Bortnowska, Kraków 1984.

Vovelle M., Śmierć w cywilizacji Zachodu. Od roku 1300 po współczesność, пер. T. Swoboda, M. Sawiczewska-Lorkowska, D. Sebczyszyn, Gdańsk 2004.

Wilk R. K. OSPPE, Śmierć i zmartwychwstanie ciała człowieka, Kraków 2015.

Wilson M., Zdrowie, postawy i wartości, пер. H. Bortnowska, [в:] Sens choroby, sens śmierci, sens życia, ред. Н. Bortnowska, Kraków 1984.

\section{"After all — even a fool knows - death does not exist, but there is a decomposition of tissues": The corporeal aspect of death in the prose of Mikhail Shishkin}

\section{Summary}

The dominant theme in Mikhail Shishkin's fiction is death, presented as considerations about the finiteness of existence, dying of oneself and others, posthumous existence, and immortality. A significant issue is also the description of the dying process and the existence of corpse after death. The article presents the theme of dying and corpse in the novels: The Taking of Izmail, Maidenhair, The Light and the Dark and Shishkin's short stories. In these works, there is a whole spectrum of thanatological motifs which can be categorized basing on the cause of death. Shishkin describes both death by natural causes and various forms of inflicting death (criminal and ritual murders, executions, killing on the battlefield, suicides). His protagonists recognize that it is the body that makes human life limited in time and death itself is perceived not as a moment of death but an uninterrupted process. Shishkin presents the changing bodies of old and sick people. Moreover, he extensively describes corpses with striking naturalist attention to details.

The corporeal aspect of death in Shishkin's prose reveals a contemporary approach to the end of human life: on the one hand, the taboo of death is clear, on the other hand - fascination with corpse is visible in mass culture. Numerous images of dying and corpses in Shishkin's fiction coexist with joyful themes affirming life, consequently, creating a vision of harmony in the world.

Keywords: Mikhail Shishkin, death, dying, killing, corpse 


\section{„Przecież śmierci - nawet głupi wie - nie ma, ale jest rozkład tkanek". Cielesny aspekt śmierci w prozie Michaiła Szyszkina}

\section{Streszczenie}

W twórczości Michaiła Szyszkina dominującym tematem jest śmierć, prezentowana jako rozważania o skończoności egzystencji, umieraniu swoim i innego, istnieniu pośmiertnym, nieśmiertelności. Wiele miejsca zajmuje też opis procesu umierania ciała i jego istnienia po śmierci. $\mathrm{W}$ artykule przedstawiono obraz umierającego i martwego ciała w powieściach: Zdobycie twierdzy Izmait, Włos Wenery i Nie dochodza tylko listy nienapisane oraz w opowiadaniach. W utworach tych występuje całe spektrum motywów tanatologicznych, które można wyodrębnić na podstawie przyczyny śmierci. Szyszkin opisuje zarówno śmierć naturalną, jak i różne formy zadawania śmierci (zabójstwa kryminalne i rytualne, egzekucje, zabijanie na polu walki, samobójstwa). Bohaterowie jego utworów dostrzegają, że to ciało sprawia, iż życie człowieka jest ograniczone w czasie, a samą śmierć postrzegają nie jako moment zgonu, a nieprzerwany proces. Pisarz przedstawia także zmieniające się ciała ludzi starych i chorych. Wiele miejsca poświęca też opisom martwych ciał, przy czym uderza w nich naturalistyczna detalizacja.

Cielesny aspekt śmierci w prozie Szyszkina ujawnia współczesne podejście do zakończenia życia ludzkiego: z jednej strony wyraźna jest tabuizacja śmierci, z drugiej — fascynacja martwym ciałem, widoczna w kulturze masowej. Liczne obrazy umierania i trupów pozostają w utworach pisarza $\mathrm{w}$ równowadze z elementami radosnymi, afirmującymi życie, tworząc z nimi wizję harmonii w świecie.

Stowa kluczowe: Michaił Szyszkin, śmierć, umieranie, zabijanie, martwe ciało 